\title{
Penerapan Teknik Ekstraksi dan Durasi Dry Heat Treatment Terhadap Mutu Benih Tomat (Lycopersicum esculentum Mill.)
}

\section{The Application of Extraction Techniques and Duration of Dry Heat Treatment on The Quality of Tomato Seed}

\author{
Ulya Savira $^{1}$, Agam Ihsan Hereri ${ }^{1}$, Rita Hayati ${ }^{\text {* }}$ \\ ${ }^{1}$ Program Studi Agroteknologi, Fakultas Pertanian, Universitas Syiah Kuala
}

\begin{abstract}
Abstrak. Penelitian ini bertujuan untuk mengetahui pengaruh teknik ekstraksi, dry heat treatment, dan interaksi antara teknik ekstraksi dan dry heat treatment terhadap mutu benih tomat. Penelitian ini dilaksanakan di Laboratorium Ilmu dan Teknologi Benih Fakultas Pertanian, Universitas Syiah Kuala Banda Aceh yang berlangsung mulai bulan Mei sampai Juli 2018. Analisa data ini menggunakan Rancangan Acak Lengkap (RAL) Pola Faktorial dengan 2 faktor dan 3 ulangan. Faktor yang diamati dalam penelitian ini adalah teknik ekstraksi dan durasi dry heat treatment. Teknik ekstraksi (T) terdiri dari 2 taraf yaitu teknik ekstraksi dengan air langsung dan teknik ekstraksi dengan $\mathrm{HCl} 1 \%$ serta dry heat treatment (DHT) dengan suhu $60{ }^{\circ} \mathrm{C}$ terdiri dari 4 taraf yaitu kontrol (tanpa DHT), 12 jam, 24 jam dan 48 jam. Parameter yang diamati yaitu kadar air benih, potensi tumbuh, daya berkecambah, kecepatan tumbuh relatif, tinggi bibit, jumlah daun, diameter pangkal batang, bobot brangkasan basah, bobot brangkasan kering dan volume akar. Hasil penelitian menunjukkan bahwa perlakuan teknik ekstraksi yang terbaik terdapat pada teknik ekstraksi dengan $\mathrm{HCl} 1 \%$ dan perlakuan durasi dry heat treatment yang terbaik terdapat pada 48 jam. Interaksi antara teknik ekstraksi dan durasi dry heat treatment yang terbaik terdapat pada teknik ekstraksi $\mathrm{HCl} 1 \%$ dengan dry heat treatment 48 jam.
\end{abstract}

Kata kunci : Teknik ekstraksi, dry heat treatment, dan mutu benih

\begin{abstract}
This research aims to determine the effect of extraction techniques, dry heat treatment and the interactions of extraction techniques and dry heat treatment on the quality of tomato seeds. This research was carried out at Laboratory of Science and Seed Technology of the Faculty of Agriculture, Syiah Kuala Banda Aceh University from May to July 2018. The research units were compiled based on a Completely Randomized Design-factorial with 2 factors and 3 replications. First factor was extraction techniques (T) with 2 treatments: extraction technique with water and extraction technique with $\mathrm{HCl} 1 \%$. The second factor was dry heat treatment (DHT) in temperature $60{ }^{\circ} \mathrm{C}$ with 4 treatments: control (non-DHT), 12 hours, 24 hours and 48 hours. The parameters observed were seed moisture content, maximum growth potential, germination rate, relative growth speed, seedling height, leaves number, plant fresh weight, plant dry weight, and root volume. The result of the research showed that the best extraction method was found in extraction with $\mathrm{HCl} 1 \%$ treatment and duration of dry heat treatment with 48 hours gave the best result on tomato seed quality. The interaction of extraction methods with $\mathrm{HCl} 1 \%$ and duration of dry heat treatment with 48 hours gave the best result on tomato seed quality.
\end{abstract}

Keyword: extraction technique, dry heat treatment, and seed quality.

\section{PENDAHULUAN}

Tomat (Lycopersicum esculentum Mill.) saat ini merupakan salah satu komoditihortikultura yang bernilai ekonomi tinggi dan masih memerlukan penanganan serius, terutama dalam hal peningkatan kuantitas dan kualitas buahnya. Tomat adalah sayuran buah yang termasuk kedalam famili Solanaceae dan tergolong tanaman semusim yang mengandung zat-zat yang berguna bagi tubuh manusia yaitu kandungan vitamin $\mathrm{A}$, vitamin $\mathrm{B}$, vitamin $\mathrm{C}$, dan mineral yang mencakup $\mathrm{Ca}, \mathrm{Mg}, \mathrm{P}, \mathrm{K}, \mathrm{Na}, \mathrm{Fe}$ (Pitojo, 2005).

Produktivitas tomat di Indonesia pada tahun 2012 sebesar 15,75 ton ha $^{-1}$ meningkat pada tahun 2013 sebesar 16,61 ton $\mathrm{ha}^{-1}$, namun terjadi penurunan produktivitas tomat pada tahun 2014 yaitu 15,52 ton ha ${ }^{-1}$. Pada tahun 2015, produktivitas tomat sebesar 16,09 ton ha ${ }^{-1}$ dan mengalami penurunan pada tahun 2016 menjadi sebesar 15,31 ton ha ${ }^{-1}$. Produktivitas tomat di Indonesia cenderung fluktuatif salah satunya dikarenakan tidak konsistennya mutu benih yang digunakan oleh petani (BPS, 2017).

Tomat tergolong kedalam buah yang berdaging dan berair (wet fleshly fruit) dan termasuk dalam tipe buah berry. Pada saat benih masak fisiologis kandungan air benih masih 
sangat tinggi dan benih diselaputi oleh lendir yang saling melekat pada biji yang mengandung bahan yang bersifat inhibitor. Lendir tersebut akan menghambat perkecambahan apabila tidak dibersihkan dengan baik, sehingga mempengaruhi mutu benih tomat (Kuswanto, 2003). Ekstraksi benih memegang peranan penting dalam proses penanganan pasca panen benih. Ekstraksi benih merupakan suatu tindakan untuk memisahkan biji calon benih dari buah sehingga diperoleh benih dalam keadaan yang bersih (Stubsgoard dan Moestrup, 1994).

Ekstraksi benih tomat termasuk kedalam ekstraksi secara basah. Teknik ekstraksi secara basah pada benih dapat dilakukan dengan berbagai cara seperti menggunakan air, fermentasi, larutan asam, dan larutan basa (Raganatha, 2014). Metode ekstraksi menggunakan larutan asam sangat efektif untuk memisahkan pulp dari biji tomat yang lebih sering digunakan dalam produsen benih yang berskala besar. Penggunakan $\mathrm{HCl}$ pada ekstraksi benih jeruk dilaporkan memberikan hasil baik, karena asam yang digunakan selain membersihkan lendir yang menempel pada benih juga meningkatkan permeabilitas kulit benih (Sadjad, 1980).

Salah satu upaya untuk mempertahankan mutu benih juga dapat dilakukan dengan $d r y$ heat treatment (DHT). Dry heat treatment merupakan perlakuan pada benih yang efektif, aplikatif, murah dan ramah lingkungan dalam usaha memproduksi benih sehat dan bermutu dengan perlakuan suhu tinggi pada benih. Dry heat treatment bertujuan untuk tercapainya kadar air yang rendah dan merata pada lot benih. Kadar air rendah pada benih-benih ortodoks sangat diperlukan untuk proses penyimpanan yang aman (Raka et al., 2012).

Berdasarkan uraian tersebut mengenai proses ekstraksi dan dry heat treatment yang dapat mempengaruhi mutu benih tomat, maka dari itu penelitan ini bertujuan untuk melihat efek dari teknik ekstraksi dan dry heat treatment.

\section{METODOLOGI PENELITIAN}

\section{Waktu dan Tempat}

Penelitian ini dilaksanakan di Laboratorium Ilmu dan Teknologi Benih Fakultas Pertanian, Universitas Syiah Kuala Banda Aceh yang berlangsung mulai bulan Mei sampai Juli 2018.

\section{Alat dan Bahan}

Alat

Alat yang digunakan dalam penelitian ini adalah autoclave, beaker glass $500 \mathrm{ml}$, petridish (plastik mika bulat, diameter $11 \mathrm{~cm}$ ) sebanyak 27 buah, sendok, toples plastik, ember, meteran, jangka sorong digital, termometer oven, cawan alumunium, ayakan 9 mesh, saringan, pinset, pisau (cutter), hand sprayer $1000 \mathrm{ml}$, timbangan analitik, timbangan analog, oven, tray sebanyak 27 buah, germinator dan meja persemaian.

\section{Bahan}

Bahan yang digunakan dalam penelitian ini adalah buah tomat varietas Warani sebanyak $4 \mathrm{~kg}, \mathrm{HCl} 2 \mathrm{ml}$, kertas buram sebanyak 27 lembar, kertas label, aquabidest $200 \mathrm{ml}$, air, hand glove, polybag ukuran $15 \times 21 \mathrm{~cm}$ isi $1 \mathrm{~kg}$ sebanyak 135 polybag, tanah top soil, dan pupuk kompos.

\section{Analisis Data}

Percobaan ini menggunakan Rancangan Acak Lengkap (RAL) Pola Faktorial. Ada 2 faktor yang diamati, yaitu faktor pertama adalah teknik ekstraksi (T) yang terdiri dari 2 taraf yaitu $\mathrm{T} 1=$ Teknik ekstraksi dengan air langsung, $\mathrm{T} 2=$ Teknik ekstraksi dengan $\mathrm{HCl} 1 \%$. 
Faktor kedua adalah Dry Heat Treatment (DHT) dengan suhu $60{ }^{\circ} \mathrm{C}$ yang terdiri dari 4 taraf yaitu $\mathrm{D} 0=$ Kontrol $($ Tanpa DHT), D1 $=12$ jam, D2 $=24$ jam dan D3= 48 jam. Dengan demikian terdapat 8 kombinasi perlakuan dengan 3 kali ulangan, sehingga diperoleh 24 satuan percobaan.

\section{Pelaksanaan Penelitian}

\section{Pemilihan Buah}

Buah tomat untuk benih diambil dari kebun petani tomat di Pondok Baru, Bener Meriah. Jenis tomat yang digunakan dalam penelitian ini yaitu varietas Warani. Buah tomat diambil dengan kriteria buah yang telah masak fisiologis (berwarna merah muda) pada saat panen kedua dengan umur panen 95 hari, buah sehat serta tidak terserang hama dan penyakit.

\section{Proses Ekstraksi Benih}

Proses ekstraksi benih diawali dengan pembelahan buah tomat untuk diambil bijinya dengan menggunakan sendok. Setiap perlakuan ekstraksi menggunakan $2 \mathrm{~kg}$ buah tomat. Buah yang telah masak dipotong secara melintang, kemudian dikeluarkan biji dengan lapisan beningnya (pulp) menggunakan sendok dan ditampung ke dalam wadah yang telah disediakan dan kulit dengan bagian buah yang terbawa dipisahkan pada wadah yang lain.

Perlakuan ekstraksi dengan air langsung dilakukan dengan cara mencuci langsung biji dari pulp yang menempel dengan air yang mengalir menggunakan saringan. Pencucian dilakukan sebanyak 4-5 kali sampai dengan lendir bersih atau yang ditandai dengan permukaan benih tidak licin. Kemudian benih diletakkan pada wadah untuk dikeringanginkan selama 2 jam.

Pelakuan teknik ekstraksi dengan $\mathrm{HCl} 1 \%$ dilakukan dengan cara $\mathrm{HCl}$ pekat sebanyak $2 \mathrm{ml}$ kemudian ditambahkan aquabidest hingga $200 \mathrm{ml}$. Larutan $\mathrm{HCl}$ tersebut dimasukkan ke dalam wadah yang telah berisi benih serta pulp dan direndam selama 2 jam. Benih yang telah di ekstraksi dibilas dengan air sebanyak 4-5 kali pencucian sampai benih bersih, kemudian benih disaring dan diletakkan pada wadah untuk dikeringanginkan selama 2 jam.

\section{Dry Heat Treatment (DHT)}

Benih tomat juga diberi perlakuan dry heat treatment (DHT). Dry heat treatment dilakukan dengan menggunakan oven yang sebelumnya telah dikalibrasi untuk menyesuaikan suhu dalam dan luar oven. Dry heat treatment dilakukan dengan 4 taraf yaitu non dry heat treatment sebagai perlakuan kontrol, dimana benih tidak diberi perlakuan pemanasan dengan dry heat treatment.

Perlakuan selanjutnya yaitu dry heat treatment dengan durasi 12, 24 dan 48 jam yang dilakukan dengan cara benih tomat dimasukkan dalam cawan, kemudian benih tersebut dimasukkan kedalam oven yang telah di atur dengan suhu $60{ }^{\circ} \mathrm{C}$. Setelah diberi perlakuan $d r y$ heat treatment, benih tomat siap untuk dikecambahkan.

\section{Uji Mutu Benih}

Proses perkecambahan benih dilakukan dengan metode Uji Diatas Kertas (UDK). Benih yang diuji adalah benih yang telah dan tanpa DHT (menurut perlakuan). Jumlah benih yang dikecambahkan untuk setiap ulangan yaitu 25 butir dengan 3 kali ulangan. Pengamatan dilakukan dari periode pertama sampai 14 hari setelah tanam.

Pada proses pembibitan, terlebih dahulu benih disemai pada tray sebanyak 25 benih dengan 3 ulangan. Kemudian dipilih sebanyak 5 bibit yang pertumbuhannya baik dan normal pada setiap tray untuk dipindah tanam ke dalam polybag yang berukuran $15 \times 21 \mathrm{~cm}$ isi $1 \mathrm{~kg}$ pada umur 14 HST. Media tanam yang digunakan untuk pembibitan yaitu tanah dan pupuk 
kompos (2:1) untuk setiap polybag. Setiap polybag ditanami dengan 1 bibit tomat kemudian polybag di tata di area pembibitan untuk diamati selama pembibitan. Selama proses pembibitan, dilakukan penyiraman menggunakan hand sprayer secara berkala sampai akhir pengamatan. Pembibitan tomat dilakukan selama 42 hari.

\section{Parameter Pengamatan}

Parameter yang diamati adalah kadar air benih, potensi tumbuh, daya berkecambah, kecepatan tumbuh relatif, tinggi bibit, jumlah daun bibit, diameter pangkal batang, bobot brangkasan basah bibit, bobot brangkasan kering bibit, dan volume akar.

\section{HASIL DAN PEMBAHASAN}

\section{Pengaruh Teknik Ekstraksi Terhadap Parameter Mutu Benih Tomat}

Hasil uji $\mathrm{F}$ pada analisis ragam menunjukkan bahwa perlakuan teknik ekstraksi berpengaruh sangat nyata terhadap kadar air, berpengaruh nyata terhadap potensi tumbuh, sedangkan tidak berpengaruh nyata terhadap daya berkecambah dan kecepatan tumbuh relatif. Rata-rata nilai kadar air benih, potensi tumbuh, daya berkecambah, dan kecepatan tumbuh relatif benih tomat akibat perlakuan teknik ekstraksi dapat dilihat pada Tabel 1.

Tabel 1. Rata-rata nilai kadar air benih (\%), potensi tumbuh (\%), daya berkecambah (\%), dan kecepatan tumbuh relatif (\%) akibat Perlakuan Teknik Ekstraksi

\begin{tabular}{lcc}
\hline \multirow{2}{*}{ Parameter } & \multicolumn{2}{c}{ Teknik Ekstraksi } \\
\cline { 2 - 3 } & $\begin{array}{c}\text { Ekstraksi Air } \\
\text { langsung }\end{array}$ & Ekstraksi HCl 1\% \\
\hline Kadar Air Benih (\%) & 7,18 & 7,56 \\
Potensi Tumbuh (\%) & $(2,64) \mathrm{a}$ & $(2,69) \mathrm{b}$ \\
& 94,35 & 98,00 \\
Daya Berkecambah (\%) & $(9,71) \mathrm{a}$ & $(9,90) \mathrm{b}$ \\
& 69,90 & 75,67 \\
Kecepatan Tumbuh Relatif (\%) & $(57,23)$ & $(61,22)$ \\
& 58,17 & 68,95 \\
& $(49,92)$ & $(56,80)$ \\
\hline
\end{tabular}

Keterangan : - Angka yang diikuti oleh huruf yang sama pada baris yang sama berbeda tidak nyata berdasarkan uji Beda Nyata Jujur (BNJ) pada taraf $\alpha=0,05$.

- ( ) Angka setetah ditransformasi. KAB dan PT menggunakan transformasi $\sqrt{x}$. DB dan KCT menggunakan transformasi ArcSin $\sqrt{p}$.

Tabel 1 menunjukkan bahwa nilai kadar air benih dan potensi tumbuh tertinggi akibat perlakuan teknik ekstraksi dijumpai pada teknik ekstraksi dengan $\mathrm{HCl} 1 \%$ yaitu 7,56 \% dan $98 \%$ yang berbeda nyata dengan teknik ekstraksi dengan air langsung $\left(\mathrm{T}_{1}\right)$. Daya berkecambah dan kecepatan tumbuh relatif yang cenderung lebih baik dijumpai pada teknik ekstraksi dengan $\mathrm{HCl} 1 \%$ meskipun secara statistik tidak memberikan pengaruh yang nyata.

$\mathrm{Hal}$ ini diduga larutan $\mathrm{HCl} 1 \%$ telah mampu mereduksi atau menghilangkan lendir daging buah (pulp) yang melekat pada biji tomat dimana lendir daging buah (pulp) mengandung zat inhibitor yaitu asam absisat yang dapat menghambat perkecambahan sehingga perlu untuk dihilangkan sebelum benih dikeringkan. Sesuai dengan pernyataan Wiguna (2013), bahwa pulp yang melekat pada biji tomat mengandung asam absisat yang merupakan zat penghambat perkecambahan dan pertumbuhan benih. Ditambahkan dengan pernyataan Raganatha (2014), penggunaan $\mathrm{HCl} 2 \%$ pada ekstraksi memberikan hasil yang 
terbaik, karena asam yang digunakan selain membersihkan lendir pada benih juga dapat meningkatkan permeabilitas kulit benih sehingga benih mudah berkecambah.

\section{Pengaruh Teknik Ekstraksi Terhadap Parameter Pertumbuhan Bibit Tomat}

Hasil uji F pada analisis ragam menunjukkan bahwa perlakuan teknik ekstraksi berpengaruh sangat nyata terhadap parameter diameter pangkal batang 7 HSPT, dan volume akar bibit serta berpengaruh nyata pada parameter potensi tumbuh, tinggi bibit 7 dan 14 HSPT, dan bobot brangkasan bibit namun berpengaruh tidak nyata terhadap parameter lainnya. Rata-rata nilai pertumbuhan bibit tomat akibat perlakuan teknik ekstraksi dapat dilihat pada Tabel 2.

Tabel 2. Rata-rata Pertumbuhan Bibit Tomat Akibat Perlakuan Teknik Ekstraksi

\begin{tabular}{lcc}
\hline & \multicolumn{2}{c}{ Teknik Ekstraksi } \\
\cline { 2 - 3 } Parameter & $\begin{array}{c}\text { Ekstraksi Air } \\
\text { langsung }\end{array}$ & Ekstraksi HCl 1\% \\
\hline Tinggi Bibit 7 HSPT (cm) & $4,06 \mathrm{a}$ & $4,50 \mathrm{~b}$ \\
Tinggi Bibit 14 HSPT (cm) & $5,94 \mathrm{a}$ & $6,68 \mathrm{~b}$ \\
Tinggi Bibit 21 HSPT (cm) & 10,22 & 10,49 \\
Tinggi Bibit 28 HSPT (cm) & 15,39 & 15,84 \\
Jumlah Daun 7 HSPT (helai) & 6,2 & 6,6 \\
Jumlah Daun 14 HSPT (helai) & 12,2 & 12,8 \\
Jumlah Daun 21 HSPT (helai) & 20,3 & 21,6 \\
Jumlah Daun 28 HSPT (helai) & 29,9 & 31,4 \\
Diameter Pangkal Batang 7 HSPT (mm) & $1,70 \mathrm{a}$ & $1,89 \mathrm{~b}$ \\
Diameter Pangkal Batang 14 HSPT (mm) & 2,65 & 2,78 \\
Diameter Pangkal Batang 21 HSPT (mm) & 3,45 & 3,55 \\
Diameter Pangkal Batang 28 HSPT (mm) & 4,26 & 4,43 \\
Bobot Brangkasan Basah Bibit (g) & 4,743 & 4,867 \\
Bobot Brangkasan Kering Bibit (g) & $0,42 \mathrm{a}$ & $0,49 \mathrm{~b}$ \\
Volume Akar (ml) & $0,5 \mathrm{a}$ & $0,6 \mathrm{~b}$ \\
\hline Kelengan :Angka yng
\end{tabular}

Keterangan : Angka yang diikuti oleh huruf yang sama pada baris yang sama berbeda tidak nyata berdasarkan uji Beda Nyata Jujur (BNJ) pada taraf $\alpha=0,05$

Tabel 2 menunjukkan bahwa tinggi bibit umur 7 dan 14 HSPT dan diameter pangkal batang umur 7 HSPT tertinggi dijumpai pada perlakuan teknik ekstraksi dengan $\mathrm{HCl} 1 \%\left(\mathrm{~T}_{2}\right)$ yang berbeda nyata dengan teknik ekstraksi dengan air langsung $\left(\mathrm{T}_{1}\right)$. Pada parameter parameter bobot brangkasan kering dan volume akar bibit tertinggi dijumpai pada perlakuan teknik ekstraksi dengan $\mathrm{HCl} 1 \%\left(\mathrm{~T}_{2}\right)$ yang berbeda nyata dengan teknik ekstraksi dengan air langsung $\left(\mathrm{T}_{1}\right)$.

Menurut Raval (2016), larutan $\mathrm{HCl}$ merupakan larutan asam yang bersifat korosif sehingga dapat membersihkan lendir yang melekat pada daging buah, namun konsentrasi dan periode aplikasi harus sesuai karena apabila larutan asam yang digunakan tanpa pengenceran maka dapat terjadi kerusakan pada benih, sehingga konsentrasi $\mathrm{HCl} 1 \%$ efektif untuk membersihkan benih dari lendir. Selain dapat menghasilkan benih yang bersih dari lendir ( pulp) yang mengandung sifat inhibitor juga dapat melunakkan kulit benih yang memudahkan proses imbibisi sehingga benih dapat berkecambah dan tumbuh menjadi bibit. Benih yang dapat berkecambah dengan baik maka pertumbuhan bagian-bagian tanaman lainnya akan lebih cepat yang ditunjukkan oleh tinggi bibit, jumlah daun bibit dan diameter pangkal bibit (Raka, 2014). 
Pada parameter bobot brangkasan kering bibit dan volume akar, teknik ekstraksi dengan $\mathrm{HCl} 1 \%$ menghasilkan nilai yang tertinggi. Hal ini diduga disebabkan kulit benih yang permeable menyebabkan proses imbibisi akan lebih cepat sehingga mempercepat pertumbuhan bibit yang juga perakaran tumbuh menjadi lebih cepat sehingga mampu menyerap unsur hara secara optimal. Benih dengan vigor tinggi dapat membentuk dan mentranslokasikan bahan baku ke poros embrio dengan cepat sehingga meningkatkan akumulasi bahan kering. Berat kering yang tinggi dapat menggambarkan pemanfaatan cadangan makanan dalam benih yang efisien (Nurussintani et al., 2012).

\section{Pengaruh Durasi Dry Heat Treatment Terhadap Parameter Mutu Benih Tomat}

Hasil uji $\mathrm{F}$ pada analisis ragam menunjukkan bahwa perlakuan durasi dry heat treatment berpengaruh sangat nyata terhadap kadar air namun tidak nyata terhadap potensi tumbuh, daya berkecambah dan kecepatan tumbuh relatif benih tomat. Rata-rata nilai kadar air benih, potensi tumbuh, daya berkecambah, dan kecepatan tumbuh relatif benih tomat akibat perlakuan durasi dry heat treatment dapat dilihat pada Tabel 3.

Tabel 3. Rata-rata Nilai Kadar Air Benih, Potensi Tumbuh, Daya Berkecambah, dan Kecepatan Tumbuh Relatif Benih Akibat Perlakuan Durasi Dry Heat Treatment

\begin{tabular}{lcccc}
\hline \multirow{2}{*}{ Parameter } & \multicolumn{4}{c}{ Durasi Dry Heat Treatment (jam) } \\
\cline { 2 - 5 } & Tanpa DHT & 12 & 24 & 48 \\
\hline Kadar Air Benih (\%) & 12,07 & 7,07 & 6,14 & 4,22 \\
& $(3,73) \mathrm{d}$ & $(2,66) \mathrm{c}$ & $(2,48) \mathrm{b}$ & $(2,05) \mathrm{a}$ \\
Potensi Tumbuh (\%) & 96,70 & 95,35 & 96,00 & 96,65 \\
& $(9,83)$ & $(9,76)$ & $(9,80)$ & $(9,83)$ \\
Daya Berkecambah (\%) & 68,47 & 82,00 & 71,34 & 69,34 \\
& $(56,26)$ & $(66,17)$ & $(57,83)$ & $(56,63)$ \\
Kecepatan Tumbuh Relatif (\%) & 62,12 & 73,60 & 60,47 & 58,06 \\
& $(52,54)$ & $(60,05)$ & $(51,17)$ & $(49,67)$ \\
\hline
\end{tabular}

Keterangan : - Angka yang diikuti oleh huruf yang sama pada baris yang sama berbeda tidak nyata berdasarkan uji Beda Nyata Jujur (BNJ) pada taraf $\alpha=0,05$.

- ( ) Angka setetah ditransformasi. KAB dan PT menggunakan transformasi $\sqrt{x}$. DB dan KCT menggunakan transformasi $\operatorname{ArcSin} \sqrt{ } p$.

Tabel 3 menunjukkan kadar air benih terendah dijumpai pada DHT 48 jam. Salah satu tujuan dari dry heat treatment adalah untuk mengurangi kadar air benih dimana agar dapat memperpanjang masa simpan benih (Somado et al., 2006) Semakin lama durasi dry heat treatment, nilai kadar air benih semakin menurun. Hal ini sejalan dengan penelitian Maulidah, et al. (2017) bahwa lama pengeringan berpengaruh dengan kadar air benih gambas, semakin lama pengeringan semakin rendah kadar air benih. Pengeringan benih tersebut bermaksud untuk menurunkan kadar air benih. Benih tomat termasuk dalam benih ortodoks, dimana benih ortodoks relatif tahan terhadap pengeringan sampai kadar air mencapai $4-5 \%$.

\section{Pengaruh Durasi Dry Heat Treatment Terhadap Parameter Pertumbuhan Bibit Tomat}

Hasil uji $\mathrm{F}$ pada analisis ragam menunjukkan bahwa durasi dry heat treatment berpengaruh sangat nyata pada parameter kadar air, tinggi bibit 21 HSPT, jumlah daun 7, 14, 21 dan 28 HSPT, dan volume akar serta berpengaruh nyata pada parameter tinggi bibit 7 dan 14 HSPT, diameter pangkal batang 7 HSPT, dan bobot brangkasan basah bibit namun berpengaruh tidak nyata terhadap parameter lainnya. Rata-rata nilai pertumbuhan bibit tomat akibat perlakuan durasi dry heat treatment dapat dilihat pada Tabel 4. 
Tabel 4. Rata-rata Pertumbuhan Bibit Tomat Akibat Durasi Dry Heat Treatment

\begin{tabular}{lcccc}
\hline \multirow{2}{*}{ Parameter } & \multicolumn{4}{c}{ Durasi Dry Heat Treatment (jam) } \\
\cline { 2 - 5 } & Tanpa DHT & 12 & 24 & 48 \\
\hline Tinggi Bibit 7 HSPT (cm) & $4,05 \mathrm{ab}$ & $4,74 \mathrm{~b}$ & $3,91 \mathrm{a}$ & $4,60 \mathrm{ab}$ \\
Tinggi Bibit 14 HSPT (cm) & $6,54 \mathrm{ab}$ & $6,48 \mathrm{ab}$ & $5,43 \mathrm{a}$ & $6,81 \mathrm{~b}$ \\
Tinggi Bibit 21 HSPT (cm) & $10,69 \mathrm{~b}$ & $10,26 \mathrm{ab}$ & $8,90 \mathrm{a}$ & $11,57 \mathrm{~b}$ \\
Tinggi Bibit 28 HSPT (cm) & 15,29 & 15,95 & 14,84 & 16,39 \\
Jumlah Daun 7 HSPT (helai) & $6,2 \mathrm{ab}$ & $7,0 \mathrm{~b}$ & $5,4 \mathrm{a}$ & $7,0 \mathrm{~b}$ \\
Jumlah Daun 14 HSPT (helai) & $13 \mathrm{~b}$ & $12,7 \mathrm{ab}$ & $10,8 \mathrm{a}$ & $13,7 \mathrm{~b}$ \\
Jumlah Daun 21 HSPT (helai) & $19,8 \mathrm{a}$ & $21,5 \mathrm{ab}$ & $19,3 \mathrm{a}$ & $23,2 \mathrm{~b}$ \\
Jumlah Daun 28 HSPT (helai) & $28 \mathrm{a}$ & $29,7 \mathrm{a}$ & $31 \mathrm{ab}$ & $34 \mathrm{~b}$ \\
Diameter Pangkal Batang 7 HSPT (mm) & $1,69 \mathrm{a}$ & $1,79 \mathrm{ab}$ & $1,76 \mathrm{ab}$ & $1,94 \mathrm{~b}$ \\
Diameter Pangkal Batang 14 HSPT (mm) & 2,71 & 2,70 & 2,60 & 2,86 \\
Diameter Pangkal Batang 21 HSPT (mm) & 3,45 & 3,62 & 3,39 & 3,59 \\
Diameter Pangkal Batang 28 HSPT (mm) & 4,25 & 4,50 & 4,24 & 4,46 \\
Bobot Brangkasan Basah Bibit (g) & $4,34 \mathrm{a}$ & $5,09 \mathrm{ab}$ & $4,03 \mathrm{a}$ & $5,74 \mathrm{~b}$ \\
Bobot Brangkasan Kering Bibit (g) & 0,38 & 0,48 & 0,44 & 0,50 \\
Volume Akar (ml) & $0,4 \mathrm{a}$ & $0,6 \mathrm{~b}$ & $0,5 \mathrm{ab}$ & $0,6 \mathrm{~b}$ \\
\hline Kel
\end{tabular}

Keterangan : Angka yang diikuti oleh huruf yang sama pada baris yang sama berbeda tidak nyata berdasarkan uji Beda Nyata Jujur (BNJ) pada taraf $\alpha=0,05$

Tabel 4 menunjukkan bahwa tinggi bibit umur 7 HSPT akibat perlakuan durasi $d r y$ heat treatment tertinggi dijumpai pada DHT 12 jam $\left(D_{1}\right)$ yaitu $4,74 \mathrm{~cm}$ sedangkan tinggi bibit umur 14 dan 21 HSPT tertinggi dijumpai pada perlakuan DHT 48 jam $\left(\mathrm{D}_{3}\right)$ yaitu sebesar 6,81 $\mathrm{cm}$ dan $11,57 \mathrm{~cm}$. Pada parameter jumlah daun umur 7 HSPT yang lebih banyak dijumpai pada DHT 12 jam $\left(D_{1}\right)$ dan DHT 48 jam $\left(D_{3}\right)$ yaitu 7 helai, jumlah daun umur 14, 21 dan 28 HSPT yang lebih banyak dijumpai pada perlakuan DHT 48 jam $\left(D_{3}\right)$ yaitu sebesar 13,7 helai, 23,2 helai dan 34 helai. Diameter pangkal batang umur 7 HSPT akibat perlakuan durasi dry heat treatment tertinggi dijumpai pada DHT 48 jam $\left(\mathrm{D}_{3}\right)$ yaitu $1,94 \mathrm{~mm}$ yang berbeda nyata terhadap perlakuan tanpa DHT $\left(\mathrm{D}_{0}\right)$ namun berbeda tidak nyata terhadap perlakuan lainnya.

Perlakuan DHT 48 jam dapat meningkatkan pertumbuhan bibit tomat, hal ini diduga benih tersebut memiliki daya tahan yang tinggi sehingga dengan adanya pemeliharaan yang baik serta lingkungan yang optimum maka dihasilkan pula bibit yang kuat. Toyoda, et al. (2004) menjelaskan bahwa dry heat treatment dapat memberikan cekaman lingkungan terhadap benih dengan mengharapkan benih mempunyai ketahanan tinggi terhadap penyakit, meningkatkan viabilitas benih tanpa menghilangkan unsur mutu benih yang lain. Sejalan dengan pernyataan Damanik (2010) bahwa benih-benih yang memiliki vigor tinggi akan mampu berkecambah kemudian dapat melanjutkan pertumbuhannya sampai menghasilkan bibit serta tanaman yang sehat dan kuat.

Bertambahnya diameter pangkal batang sejajar dengan pertumbuhan tinggi tanaman, dikarenakan proses translokasi unsur hara dari dalam tanah menuju bagian daun melalui batang yang diangkut oleh jaringan xylem dan floem. Proses pengangkutan yang terjadi akan melalui batang sehingga diameter batang akan terus menerus meningkat untuk memperlancar dalam proses pengangkutan fotosintat dan unsur hara. Pertambahan jumlah daun diduga dikarenakan adanya percabangan. Menurut Evan (1975), semakin tinggi pertumbuhan tanaman berpengaruh terhadap terbentuknya jumlah cabang primer pada tanaman.

Parameter bobot brangkasan basah tertinggi dijumpai pada perlakuan DHT 48 jam $\left(\mathrm{D}_{3}\right)$ yaitu 5,745 g, sedangkan parameter volume akar tertinggi dijumpai pada perlakuan DHT 12 jam $\left(D_{1}\right)$ dan 48 jam $\left(D_{3}\right)$ yaitu $0,6 \mathrm{ml}$. Hal ini disebabkan bagian akar bibit tomat tumbuh dan berkembang lebih baik sehingga lebih cepat mempunyai kemampuan mendukung 
pertumbuhan bagian lainnya. Bobot brangkasan basah tergantung pada air yang terkandung dalam organ-organ tanaman. Ketersediaan air didalam tanah akan memaksimalkan pertumbuhan tanaman dan meningkatkan berat tanaman itu sendiri. Jumlah air yang diserap melalui akar akan ditranslokasikan ke seluruh bagian tanaman (Handoyo, 2010). Hal ini sejalan dengan penelitian Widayanthi, et al. (2017) bahwa benih cabai rawit dengan perlakuan dry heat treatment menghasilkan tinggi bibit, jumlah daun bibit, panjang akar, berat basah dan berat kering bibit yang lebih tinggi dibandingkan benih yang tidak diberikan perlakuan $d r y$ heat treatment.

\section{Interaksi antara Teknik Ekstraksi dan Durasi Dry Heat Treatment Terhadap Parameter Mutu Benih Tomat}

Interaksi antara teknik ekstraksi dan durasi dry heat treatment menunjukkan berpengaruh sangat nyata terhadap parameter bobot brangkasan kering bibit, serta berpengaruh nyata terhadap parameter tinggi bibit umur 21 HSPT dan bobot brangkasan basah bibit.

Tabel 5. Rata-rata Pertumbuhan Bibit Tomat akibat Interaksi antara Teknik Ekstraksi dan Durasi Dry Heat Treatment

\begin{tabular}{ccccc}
\hline \multirow{2}{*}{ Parameter } & $\begin{array}{c}\text { Durasi Dry Heat } \\
\text { Treatment }\end{array}$ & \multicolumn{2}{c}{ Teknik Ekstraksi } & BNJ $_{0,05}$ \\
\cline { 2 - 4 } & & $\begin{array}{c}\text { Ekstraksi air } \\
\text { langsung }\end{array}$ & $\begin{array}{c}\text { Ekstraksi HCl } \\
1 \%\end{array}$ & \\
\hline Tinggi Bibit 21 HSPT & Tanpa DHT & $9,75 \mathrm{ab}$ & $11,62 \mathrm{~b}$ & 2,64 \\
& 12 & $11,07 \mathrm{ab}$ & $9,45 \mathrm{ab}$ & \\
& 24 & $8,54 \mathrm{a}$ & $9,25 \mathrm{ab}$ & \\
Bobot Brangkasan Basah & 48 & $11,50 \mathrm{~b}$ & $11,64 \mathrm{~b}$ & \multirow{2}{*}{ Tanpa DHT } \\
& 12 & $4,179 \mathrm{a}$ & $4,512 \mathrm{a}$ & 2,35 \\
& 24 & $4,278 \mathrm{ab}$ & $4,275 \mathrm{a}$ & \\
Bobot Brangkasan Kering & 48 & $4,608 \mathrm{ab}$ & $3,798 \mathrm{a}$ & \\
& Tanpa DHT & $0,351 \mathrm{a}$ & $0,418 \mathrm{ab}$ & 0,24 \\
& 12 & $0,507 \mathrm{ab}$ & $0,463 \mathrm{ab}$ & \\
& 24 & $0,430 \mathrm{ab}$ & $0,462 \mathrm{ab}$ & \\
& 48 & $0,396 \mathrm{ab}$ & $0,616 \mathrm{~b}$ &
\end{tabular}

Keterangan : Angka yang diikuti oleh huruf yang sama berbeda tidak nyata berdasarkan uji Beda Nyata Jujur (BNJ) pada taraf $\alpha=0,05$.

Tabel 5 menunjukkan bahwa tinggi bibit 21 HSPT, bobot brangkasan basah dan bobot brangkasan kering yang terbaik dijumpai pada kombinasi perlakuan teknik ekstraksi dengan $\mathrm{HCl} 1 \%$ dan DHT 48 jam $\left(\mathrm{T}_{2} \mathrm{D}_{3}\right)$.

Hal ini menunjukkan bahwa teknik ekstraksi menggunakan larutan $\mathrm{HCl} 1 \%$ terlihat efektif meningkatkan biomassa bibit tomat jika diikuti dengan perlakuan DHT pada taraf 48 jam. Pertambahan biomassa adalah indikator penting tentang informasi adanya fenomena pertumbuhan tanaman. Pertumbuhan adalah interaksi berbagai faktor internal dan eksternal tanaman yang dapat meningkatkan pertambahan biomassa tanaman, yang bersifat irrevesible (Lakitan, 2015). Bobot brangkasan basah dan bobot brangkasan kering tanaman merupakan parameter pertumbuhan tanaman yang sering digunakan untuk mengetahui besarnya fotosintat yang dibentuk dan simpan oleh tanaman. Perlakuan dry heat treatment 48 jam bertujuan untuk menurunkan kadar air benih sebelum dikecambahkan, dimana setelah ekstraksi benih kadar air benih masih tinggi. Penurunan kadar air pada benih ortodoks sampai pada batas 
yang aman, akan menghasilkan daya tumbuh yang lebih baik. Hasil penelitian Siadi et al. (2012) menunjukkan bahwa parameter tinggi tanaman cabai rawit tertinggi diperoleh pada perlakuan dry heat treatment 72 jam yaitu $74,97 \mathrm{~cm}$.

\section{SIMPULAN DAN SARAN}

Teknik ekstraksi berpengaruh sangat nyata terhadap parameter kadar air benih, diameter pangkal batang 7 HSPT dan volume akar bibit, sedangkan berpengaruh nyata terhadap potensi tumbuh, tinggi bibit 7 dan 14 HSPT, serta bobot brangkasan kering bibit. Teknik ekstraksi terbaik dijumpai pada teknik ekstraksi $\mathrm{HCl} 1 \%$.

Durasi dry heat treatment berpengatuh sangat nyata terhadap parameter kadar air benih, tinggi bibit 21 HSPT, jumlah daun 7, 14, 21 dan 28 HSPT, dan volume akar bibit. Sedangkan berpengaruh nyata terhadap tinggi bibit 7 dan 14 HSPT, diameter pangkal batang 7 HSPT, dan bobot brangkasan basah bibit. Durasi dry heat treatment terbaik dijumpai pada DHT 48 jam.

Adapun interaksi antara teknik ekstraksi dengan durasi dry heat treatment yang sangat nyata pada bobot brangkasan basah dan interaksi yang nyata pada tinggi bibit 21 HSPT dan bobot brangkasan kering bibit. Interaksi yang terbaik yaitu ekstraksi dengan $\mathrm{HCl} 1 \%$ dan DHT 48 jam.

Penelitian ini perlu dilakukan lebih lanjut dengan kombinasi cara ekstraksi benih tomat yaitu penggunaan asam $\mathrm{HCl}$ atau $\mathrm{HNO}_{3}$ melalui pengadukan serta dry heat treatment terhadap viabilitas benih dan pertumbuhan dan hasil tanaman tomat atau tanaman sejenisnya.

\section{DAFTAR PUSTAKA}

Badan Pusat Statistik dan Direktorat Jendral Hortikultura. 2017. Produktivitas Sayuran di Indonesia. ２012-2016.http://www.pertanian.go.id/Data5tahun/HortiATATP2016/4 Produktifitas\%20\%20Nasuonal\%20Sayuran.pdf [17 Februari 2018]

Damanik, S., M. Syakir., M. Tasma dan Siswanto. 2010. Budidaya dan Pasca Panen Karet. Pusat Penelitian dan Pengembangan Perkebunan, Bogor.

Evan, L.T. 1975. The Physiology Basis of Yield. Crop Physiology. Cambridge University Press

Handoyo, G.N. 2010. Respon tanaman caisin (Brasscia chinensis) terhadap pupuk daun NPK (16-20-25) di dataran tinggi. Skripsi. Fakultas Pertanian. Jurusan Budidaya Pertanian. IPB, Bogor.

Kuswanto, H. 2003. Teknologi Pemprosesan, Pengemasan Dan Penyimpanan Benih. Kanisius, Yogyakarta.

Lakitan, B. 2015. Dasar- dasar Fisiologi Tanaman. Rajawali Press, Jakarta

Maulidah, N.I., A. Sumeru. 2017. Pengaruh tingkat kematangan dan lama pengeringan terhadap mutu benih gambas hibrida (Luffa acutangula). Jurnal Produksi Tanaman 5 (3): 417-424.

Nurassintani, W., Damanhuri dan S.L. Purnamaningsih. 2012. Perlakuan pematahan dormansi terhadap daya tumbuh benih 3 varietas kacang tanah (Arachis hypogea). Jurnal Produksi Tanaman 1 (1): 86-93

Pitojo, Setijo. 2005. Budidaya Tanaman Tomat. Kanisius, Yogyakarta.

Raganatha, I.Y., I Gusti N.R., I Ketut S. 2014. Daya simpan benih tomat (Lycopersicum esculentum Mill.) hasil beberapa teknik esktraksi. E- Jurnal Agroteknologi Tropika 3 (3): 183-190 
Raka, G.N., M. Astiningsih, D.N Nyana, dan K. Siadi. 2012. Pengaruh dry heat treatment terhadap daya simpan benih cabai rawit (Capsicum frutescens L.). J. Agric. Sci. and Biotechnol 1 (1): 1-10

Raval, A., N. Sasidharan., Kalyan R. 2016. Effect of seed extraction procedures on seed quality parameters in tomato. Advances in Life Sciences 5 (20): 9020-9024

Sadjad, S. 1980. Teknologi Benih dalam Masalah Vigor. Dasar-dasar Teknologi Benih. Departemen Agronomi Faperta, IPB. Bogor.

Siadi, I.K., G.N. Raka., G.N.W. Purwadi. 2012. Produksi benih cabai rawit (Capsicum frutescens L.) bebas TMV (Tobacco Mosaic Virus) Melalui Dry Heat Treatment. Agrotrop 2 (1): 77-84

Somado, E. A., A.A. Ogunbayo, K. Sanni and D.D. Tia. 2006. Comparative studies of drying methods on the seed quality of interspesific NERICA rice varieties (Oryza glaberrima x Oryza sativa). African Journal of Biotechnology, 5 (18): 1618-1624.

Stubsgoard and Moestrup. 1994. Seed Processing, Training Course and Seed Procurement in Association with Danagro Adviset A/S. PT. Ardes Perdana and Danida Forest Seed Center. Bogor.

Toyoda, K., Y. Hikichi, S. Takeuchi, A. Okumura, S. Nasu,T. Okuno and K. Suzuki. 2004. Efficient inactivation of pepper mild mottle virus (PMMoV) in harvested seed in green epper (Capsium annum.L) assessed by a reverse transcription and polymerase chain reaction (RT-PCR) based amplification. Scientific Reports of The Faculty of Agriculture. Okayama University. Vol. 29.

Wiguna, F. 2013. Perbaikan viabilitas dan kualitas fisik benih cabai melalui pengaturan lama fermentasi dan penggunaan $\mathrm{NaOCl}$ pada saat pencucian benih. Jurnal Mediagro. 2 (2): $68-79$ 